\title{
ŻYCIE I DZIAŁALNOŚĆ NAUKOWO-DYDAKTYCZNA KS. PROF. DR. HAB. KRZYSZTOFA KONECKIEGO
}

Ksiądz prof. dr hab. Krzysztof Konecki urodził się 1 lipca 1950 roku w Goliszewie, na ziemi kaliskiej. W latach 1964-1968 uczęszczał do I Liceum Ogólnokształcącego im. Adama Asnyka w Kaliszu. Bezpośrednio po uzyskaniu świadectwa dojrzałości w 1968 roku wstąpił do Wyższego Seminarium Duchownego we Włocławku. Po ukończeniu studiów filozoficzno-teologicznych, w roku 1974 otrzymał z rąk Biskupa Włocławskiego Jana Zaręby święcenia prezbiteratu. W tym samym roku rozpoczął pracę duszpasterską jako wikariusz w parafii pw. Najświętszego Serca Pana Jezusa w Lubieniu Kujawskim (1974-1977).

W latach 1975-1978 odbył studia specjalistyczne z liturgiki w ówczesnej Akademii Teologii Katolickiej w Warszawie. Pracę magisterską pt. Motywy paschalne $w$ odnowionych obrzędach pogrzebu napisał pod kierunkiem ks. dr. Stanisława Czerwika, p.o. kierownika Katedry Liturgiki ATK (od 1981 roku: dr. hab.; od 1999 roku: prof. nauk teologicznych).

Studia z liturgiki kontynuował w latach 1978-1983 w Papieskim Instytucie Liturgicznym św. Anzelma oraz w Papieskim Uniwersytecie Urbanianum w Rzymie. Na tej ostatniej uczelni przedłożył w 1983 roku pracę doktorską zatytułowaną Le Orationes pro defunctis del Missale Romanum 
di Paolo VI, której promotorem był prof. Tommaso Federici. Stopień naukowy doktora ks. K. Konecki nostryfikował na Wydziale Teologii Katolickiego Uniwersytetu Lubelskiego w dniu 26 marca 1985 roku.

W roku 1983 rozpoczął wykłady z teologii liturgii w Wyższym Seminarium Duchownym we Włocławku oraz w Instytucie Teologiczno-Pastoralnym we Włocławku i w Kaliszu. Od roku 1983 pełni nieprzerwanie posługę ceremoniarza katedralnego w Bazylice Katedralnej we Włocławku, zajmuje się formacją liturgiczną alumnów oraz redaguje Porządek Służby Bożej Diecezji Włocławskiej. W latach 1983-1992 był prefektem studiów Wyższego Seminarium Duchownego we Włocławku, natomiast od roku 1992 do roku 1995 pełnił funkcję wicerektora. W latach 1995-1996 przebywał na stypendium habilitacyjnym najpierw w Rzymie, a później w Monachium.

Po odbyciu kolokwium habilitacyjnego w dniu 23 czerwca 1997 roku, na podstawie oceny ogólnego dorobku naukowego i przedstawionej rozprawy habilitacyjnej pod tytułem Konsekracja dziewic $w$ odnowie liturgicznej Soboru Watykańskiego II, decyzją Rady Wydziału Teologicznego Akademii Teologii Katolickiej w Warszawie ks. dr Krzysztof Konecki uzyskał stopień naukowy doktora habilitowanego nauk teologicznych w zakresie liturgiki. Stopień ten został zatwierdzony przez Centralną Komisję ds. Tytułu Naukowego i Stopni Naukowych w Warszawie w dniu 24 listopada 1997 roku. Recenzentami w przewodzie habilitacyjnym byli: ks. prof. dr hab. Jerzy Józef Kopeć, ks. prof. dr hab. Bogusław Nadolski oraz ks. prof. dr hab. Jerzy Stefański.

Z dniem 1 października 1999 roku został zatrudniony na etacie adiunkta w Instytucie Studiów nad Rodziną Uniwersytetu Kardynała Stefana Wyszyńskiego w Warszawie. W roku 2001, po utworzeniu Wydziału Teologicznego na Uniwersytecie Mikołaja Kopernika w Toruniu, otrzymał nominację na stanowisko profesora UMK. Został również powołany do pełnienia funkcji kierownika Zakładu Teologii Liturgii na Wydziale Teologicznym UMK. W 2010 roku na podstawie oceny dorobku naukowego i przedstawionej rozprawy naukowej pt. Rok liturgiczny i Kalendarz $w$ reformie Soboru Watykańskiego II otrzymał tytuł naukowy profesora nauk teologicznych, a w 2015 roku stanowisko profesora zwyczajnego na Uniwersytecie Mikołaja Kopernika. W wyniku reorganizacji struktury Wydziału Teologicznego UMK, latach 2014-2019 pełnił funkcję kierow- 
nika Katedry Teologii Praktycznej, którą utworzono z dotychczasowych dwóch Zakładów: Teologii Liturgii oraz Katechetyki i Pedagogiki Religii.

W latach 1989-1994 był członkiem Komisji Episkopatu Polski ds. Liturgii i Duszpasterstwa Liturgicznego, a od 2001 roku jest konsultorem Komisji Episkopatu Polski ds. Kultu Bożego i Dyscypliny Sakramentów. W latach 2017-2019 wchodził w skład Komitetu Nauk Teologicznych Polskiej Akademii Nauk.

Ksiądz prof. Krzysztof Konecki jest założycielem i redaktorem naukowym czasopisma „Teologia i Człowiek”, ukazującego się na Wydziale Teologicznym UMK od 2003 roku. Wydanie niniejszego, pięćdziesiątego - a więc jubileuszowego - tomu tego cennego periodyku zbiegło się z jubileuszem jego Redaktora Naczelnego.

Dorobek naukowy ks. prof. dr. hab. Krzysztofa Koneckiego obejmuje pozycje naukowe, popularnonaukowe i popularyzatorskie. Na publikacje naukowe składa się kilka książek i kilkadziesiąt artykułów. W niniejszym opracowaniu przywołamy jedynie niektóre z nich.

Wśród książek należy wymienić: Le Orationes pro defunctis del Missale Romanum di Paolo VI, Roma 1983; Konsekracja dziewic w odnowie liturgicznej Soboru Watykańskiego II, Włocławek 1997; Nasze sprawowanie Eucharystii, Włocławek 2007; Rok liturgiczny i Kalendarz w reformie Soboru Watykańskiego II, Toruń 2010; Czas z Chrystusem. Rok liturgiczny, Włocławek 2014; Instrukcja o muzyce w świętej liturgii „Musicam sacram”. Prace redakcyjne, Torun 2016.

W dorobku naukowym ks. prof. Krzysztofa Koneckiego można wyróżnić następujące kierunki badawcze:

- badania nad euchologią zreformowanych ksiąg liturgicznych

Jeden z podstawowych kierunków prac naukowych Jubilata stanowi analiza teologiczno-liturgiczna posoborowych ksiąg liturgicznych rzymskich. Wykorzystując metody stosowane w hermeneutyce liturgii, ks. prof. Konecki zajmuje się studium i interpretacją tekstów euchologijnych zreformowanych ksiąg liturgicznych. Wychodzi z założenia, że nie ma reformy liturgicznej i nie ma jej przyjęcia w konkretnej rzeczywistości Kościoła bez odnowy i bez recepcji ksiąg liturgicznych. Wielkie dzieło 
odnowy liturgii dokonane na II Soborze Watykańskim zostało zdefiniowane i wyrażone w jego pierwszym dokumencie, czyli Konstytucji o Świętej Liturgii. Jednak na sposób „praktyczny” zostało zawarte w odnowionych księgach liturgicznych (Od reformy liturgii do odnowy Kościoła, w: Laudate Dominum, red. K. Konecki, Gniezno 2005, s. 153-165). Ostatni etap realizacji soborowej odnowy liturgii polega więc na wdrażaniu w życie nowych ksiąg liturgicznych. To ważne zadanie tylko pozornie może wydawać się łatwe i tylko na pozór dotyczy ono wyłącznie duszpasterzy. W pierwszej kolejności powinny je podejmować ośrodki naukowe i centra badawcze, które poprzez swoje prace naukowe i publikacje przybliżają zarówno ducha, jak i literę odnowionych tekstów liturgicznych. Kierując się tym fundamentalnym dla uprawianej przez siebie dyscypliny teologicznej założeniem, w badaniach naukowych zreformowane księgi liturgiczne, zwłaszcza te dostosowane do polskich warunków, Jubilat uczynił kwestią priorytetową. W swojej pracy - zarówno badawczej, jak i dydaktycznej starał się na bieżąco zapoznawać czytelników i słuchaczy z ukazującymi się kolejno łacińskimi i polskimi edycjami nowych ksiąg liturgicznych, zwracając uwagą na ich zawartość teologiczną i znaczenie duszpasterskie. W studium nad euchologią ks. Konecki uwzględnia cały kontekst analizowanych tekstów, w tym ich źródła historyczne. Przeprowadza także niezbędną analizę semantyczną. Jednak przede wszystkim pragnie wydobyć z nich istotne treści teologiczno-liturgiczne i pastoralne.

Pierwszą poważną próbą takiej analizy tekstów euchologijnych, po napisaniu pracy magisterskiej, której część ukazała się drukiem ( Tajemnica paschalna $w$ euchologii, czytaniach biblijnych oraz $w$ symbolach odnowionej liturgii pogrzebu, „Studia Theologica Varsaviensia” 20 (1982) nr 1, s. 191-209), była dysertacja doktorska pt. Le Orationes pro defunctis del Missale Romanum di Paolo VI, Roma 1983. Do tej problematyki ks. K. Konecki nawiązał także w opracowaniu Teologia liturgii Mszy za zmarlych, w: Mszał ksiegga życia chrześcijańskiego, red. B. Nadolski, Poznań 1986, s. 207-234.

Podejmując analizę zawartości teologicznej formuł obrzędowych, Ksiądz Profesor dąży przede wszystkim do ustalenia wymowy dogmatycznej i kerygmatycznej tekstów współczesnej liturgii i związanych z nimi znaków, symboli, gestów i czynności kultycznych jako faktorów Bożego Objawienia i przejawów wiary chrześcijańskiej według znanej zasady: ut 
legem credendi lex statuat supplicandi. Tok jego rozumowania i procedury hermeneutycznej jest oparty na świadomości, że liturgia powinna być zawsze rozpatrywana $\mathrm{w}$ kontekście ekonomii zbawienia. Tę metodę badawczą i technikę studium tekstów liturgicznych ks. K. Konecki zastosował w pełnym wymiarze przede wszystkim w swojej rozprawie habilitacyjnej zatytułowanej Konsekracja dziewic w odnowie liturgicznej Soboru Watykańskiego II, Włocławek 1997, ss. 298. Dodajmy, że jest to do tej pory jedyna w Polsce monografia podejmująca teologiczną problematykę dziewictwa konsekrowanego.

Jubilat, po uzyskaniu stopnia doktora habilitowanego, stosował w wielu artykułach i opracowaniach metody badań hermeneutycznych. Zakres analizowanych tam formuł euchologijnych jest bardzo szeroki i różnorodny. Obejmuje on teksty mszalne i teksty liturgii godzin, a także formuły liturgii sakramentów i formuły związane ze sprawowaniem sakramentaliów. Odzwierciedleniem tych zainteresowań badawczych są liczne artykuły: Święty Józef w posoborowych tekstach Mszału i Liturgii godzin, „Ateneum Kapłańskie” 128 (1997) z. 527, s. 73-80; Euchologia mszalna za zmarłego biskupa, „Studia Włocławskie” 10 (2007) s. 269-279; Modlitwy za zmarlego prezbitera w Mszale Rzymskim Pawła VI, w: Confitemini Domino, quoniam bonus, red. J. Nowak, Warszawa 2007, s. 409-420; Paschalny wymiar liturgicznego kultu męczenników, „Ateneum Kapłańskie” 135 (2000) z. 549-550, s. 227-239; Święty Kazimierz Królewicz w tekstach Mszału Rzymskiego Pawła VI i Liturgii godzin, „Studia Włocławskie” 11 (2009) s. 37-54; Struktura i teologia modlitwy konsekracyjnej odnowionych obrzędów święceń kapłańskich, w: Liturgia Domus Carissima, red. A. Durak, Warszawa 1998, s. 206-219; Struktura i teologia modlitwy święceń biskupich, w: W Panu złożłłem nadzieje, red. R. Andrzejewski i in., Włocławek 2002, s. 329-340; Struktura i teologia modlitwy święceń odnowionych obrzędów diakonatu, „Studia Włocławskie” 6 (2003) s. 265-273; Maryja w obrzędach koronacji swojego wizerunku, „Roczniki Teologiczne” 52 (2005) nr 8, s. 179-178; Struktura i teologia modlitwy konsekracyjnej odnowionych obrzędów konsekracji dziewic, „Teologia i Człowiek” 3 (2004) s. 133-144; Euchologia obrzędu święceń prezbiteratu, „Ateneum Kapłańskie” 154 (2010) z. 607, s. 420-439; Sprawowanie błogosławieństw wydarzeniem kościelnym, „Seminare” 13 (1997) s. 13-22; Błogosławieństwa w życiu Kościoła, „Studia Włocławskie” 5 (2002) s. 150-160; Akcenty Ma- 
ryjne w „Obrzędach profesji zakonnej” i „Obrzędach konsekracji dziewic”, „Anamnesis” 32 (2003) nr 1, s. 46-51; Antynomia światła i ciemności $w$ euchologii Wigilii Paschalnej, w: Edukacja - kultura - teologia, red. K. Konecki, I. Werbiński, Toruń 2003, s. 739-748; Obrzęd błogosławienia kierowców i pojazdów mechanicznych 25 lipca lub w innym dniu, „Roczniki Teologiczne" 45 (1998) nr 8, s. 349-356; Błogosławieństwo wody w posoborowych ksieggach liturgicznych, w: Veritas cum caritate - intellegentia cum amore, red. C. Rychlicki, I. Werbiński, Toruń 2011, s. 215-241.

Badania nad teologiczną zawartością posoborowych ksiąg liturgicznych ks. prof. K. Konecki przedstawiał też w ramach aktywności dydaktycznej, między innymi podczas wykładów monograficznych o tej tematyce prowadzonych w Uniwersytecie Mikołaja Kopernika: Teologiczno-liturgiczne założenia odnowionej ksieggi błogosławieństw; Treści teologiczno-liturgiczne odnowionych obrzędów konsekracji dziewic; Zadania i obowiązki kapłana wynikające z obrzędu święceń.

- posoborowy kształt liturgii godzin

W kręgu badań nad wymiarem teologicznym posoborowej liturgii znaczące miejsce zajmują u ks. prof. K. Koneckiego zainteresowania liturgią godzin, która należy do najważniejszych celebracji liturgicznych Kościoła. Sprawuje się ją - tak w formie indywidualnej, jak i wspólnotowej - kilkakrotnie w ciągu każdej doby, chociaż wciąż - niestety - nie przy tak licznym udziale wiernych, jak Eucharystię, czy inne sakramenty i sakramentalia. Jubilat wielokrotnie podkreśla w swoich publikacjach, że całe novum zreformowanej liturgii godzin wyraża się głównie w jej teologii, którą należy widzieć w szerokim kontekście pogłębionej refleksji teologicznej Ojców Soboru nad liturgią.

Najgłębszy teologiczny sens liturgii godzin - przede wszystkim jako anamnezy Misterium Chrystusa - przedstawił Ksiądz Profesor w takich opracowaniach, jak: Celebracja liturgii godzin anamneza Misterium Chrystusa, „Teologia i Człowiek” 1 (2003) s. 71-81; Natura liturgii godzin, „Studia Włocławskie” 1 (1998) s. 71-76; Chrystologiczny wymiar liturgii godzin, „Studia Włocławskie” 2 (1999) s. 132-139; Anamnetyczny charakter liturgii godzin, w: Mirabile Laudis Canticum, Liturgia godzin: dzieje i teologia, red. H. J. Sobeczko, Opole 2008, s. 177-183; Duchowość 
liturgii godzin, „Studia Włocławskie” 14 (2012) s. 161-169; Eklezjalny walor liturgii godzin, „Teologia i Człowiek” 7-8 (2006) s. 123-132. W tym ostatnim artykule warte podkreślenia jest przypomnienie przez Autora, że liturgia godzin jest „darem i własnością” całego Kościoła”, a nie jedynie osób duchownych.

Dokonana przez Księdza Profesora kwerenda prowadzi do wniosku, że pomimo upływu kilku dziesięcioleci od ukazania się zreformowanej księgi Liturgia Horarum, a także ustaleń i decyzji II Polskiego Synodu Plenarnego (o czym Jubilat pisał w artykule Liturgia Godzin i sakramentalia $w$ świetle dokumentów II Polskiego Synodu Plenarnego, w: Liturgia w Dokumentach II Polskiego Synodu Plenarnego, red. K. Matwiejuk, Radom 2004, s. 79-90), w wymiarze duszpasterskim liturgia godzin - używając określeń Autora - jeszcze nie „zaistniała” i ciągle czeka na „większe zauważenie”. Obserwując codzienną praxis Kościoła, w dalszym ciągu odnosi się wrażenie, jakby zarezerwowana była wyłącznie dla duchownych i osób życia konsekrowanego, nie zaś przeznaczona dla całego ludu Bożego (tak, jak tego chce i jak naucza ostatni Sobór). Stąd w ramach pracy dydaktycznej na Wydziale Teologicznym UMK ks. prof. K. Konecki podjął na wykładach monograficznych temat Liturgia godzin modlitwa całego ludu Bożego.

- badania nad znaczeniem i wymową symboliki liturgicznej

Kolejnym nurtem naukowych poszukiwań ks. prof. Krzysztofa Koneckiego jest wymowa i znaczenie symboliki liturgicznej. Wybór tego kierunku badań podyktowany został - jak wynika z publikacji Jubilata samą naturą liturgii, która jest sprawowana pod osłoną znaków i symboli, ale także dającą się zaobserwować ewolucją współczesnego człowieka w podejściu do symboli, w tym zwłaszcza do znaków i symboli religijnych i liturgicznych. Człowiek w gruncie rzeczy wciąż pozostaje, mimo dokonujących się wielu przemian, homo symbolicus i ma prawo - w ocenie ks. prof. Koneckiego - do poznania głębszych warstw symboliki liturgicznej.

Jubilat w swoich publikacjach ukazuje nie tylko historyczne rozumienie różnych znaków i symboli, jak na przykład nakładanie rąk w sakramencie pokuty i pojednania (Nałożenie rąk w liturgii sakramentu 
pokuty i pojednania, w: W stużbie Kościołowi i nauce, red. J. Bagrowicz i in., Włocławek 1994, s. 96-100), czy też w sakramencie święceń ( $N a-$ łożenie rąk $w$ odnowionych obrzędach święceń, "Studia Włocławskie" 4 (2001) s. 190-197), ale koncentruje się również na znaczeniu wynikającym z treści formuł, które znakom sakramentalnym towarzyszą. Wspomniany gest nałożenia rąk uwyraźnia pneumatologiczny i pneumahagijny wymiar sakramentu pokuty i święceń. To Duch Święty jest Autorem przemiany w człowieku, Dawcą nowego życia i wchodzenia człowieka w upragnioną wolność. Równie mocno teologiczno-antropologiczny wymiar symboliki liturgicznej ujawnia się w liturgii pogrzebu. Gesty i znaki, zwykle odbierane przez uczestników granicznej sytuacji z wielką uwagą, stają się nośnikami paschalnej nadziei, czyli „przejścia na drugi brzeg ludzkiej egzystencji" (Paschalna wymowa symboli odnowionych obrzędów pogrzebu, „Ateneum Kapłańskie” 95 (1980) z. 430, s. 199-206; także w: „Studia Theologica Varsaviensia” 20 (1982) nr 1, s. 190-210). Z kolei tak często wykonywany znak krzyża jest znakiem przynależności do Chrystusa i wyznaniem wiary w Niego, „znakiem błogosławieństwa osób i rzeczy”, „włączenia w Misterium Chrystusa”, „zapowiedzią ostatecznego pojednania z Bogiem w wspólnocie zbawionych" (Symbolika krzyża w odnowionej liturgii sakramentów, „Ateneum Kapłańskie” 109 (1987) z. 470, s. 67-78). Problematykę symbolu podejmuje ks. Konecki również w artykule Symbolika obrzędów dedykacji kościoła, „Studia Włocławskie” 3 (2000) s. 133-147; oraz w opracowaniu Postawy w liturgii, „Seminare” 17 (2001) s. $145-156$.

W omawiany nurt badań wpisuje się także wykład monograficzny Jubilata zatytułowany Teologia znaku zgromadzenia liturgicznego.

- badania nad chrześcijańskim przeżywaniem niedzieli

W naukowym dorobku ks. prof. K. Koneckiego nie zabrakło badań nad chrześcijańskim świętowaniem niedzieli. Przemiany gospodarczo-społeczne i polityczne zachodzące w świecie, a zwłaszcza w Europie, "zachwiały” - co podkreśla Jubilat w swoich publikacjach - podstawami chrześcijańskiego przeżywania niedzieli także w naszym kraju. Znalazło to swój rezonans choćby we wciąż zmniejszającej się frekwencji wiernych na niedzielnej Eucharystii. Zauważa się, że chrześcijanie systematycznie 
tracą poczucie sacrum w odniesieniu do Dnia Pańskiego. Przez większą część wiernych niedziela pojmowana jest przede wszystkim jako dzień wolny od pracy, dzień odpoczynku, dzień wzajemnych spotkań, nie zaś jako Dzień Pański, czyli poświęcony Bogu dzień wspólnej Eucharystii wierzących. W publikacjach dotyczących chrześcijańskiego obchodzenia niedzieli ks. Konecki postuluje podjęcie wysiłku zmierzającego do przywrócenia świątecznego charakteru niedzieli głównie poprzez pogłębienie u wiernych świadomości religijnej. Tę z kolei można osiągnąć poprzez systematyczną formację liturgiczną. Ignorancja liturgiczna jest bowiem jedną z podstawowych przyczyn ignorancji religijnej, o czym niejednokrotnie przypominali pionierzy ruchu odnowy liturgicznej (Poczatki ruchu odnowy liturgicznej w Polsce, w: Johanes Pinsk prekursor posoborowej odnowy liturgicznej, red. A. Krzystek, Szczecin 2008, s. 123-145).

Ksiądz Profesor zauważa również, że dzieło odnowy chrześcijańskiego ducha w przeżywaniu niedzieli może się dokonać poprzez sam sposób sprawowania niedzielnej liturgii Mszy świętej (Msza święta sercem i szczytem świętowania niedzieli, „Teologia i Człowiek” 6 (2005) s. 43-52). Także ożywienie i pogłębienie świadomości chrzcielnej oraz wynikających z przyjętego chrztu konsekwencji może się w tym procesie odnowy okazać bardzo przydatne i owocne, o czym Jubilat napisał w artykule Celebracja niedzieli jako konsekwencja sakramentu chrztu, „Liturgia Sacra” 14 (2008) nr 1, s. 5-19.

Problematyce rewaloryzacji niedzieli wśród wiernych świeckich miało służyć zorganizowane przez Księdza Profesora dwudniowe sympozjum naukowe Pamiętaj abyś dzień święty święcił (Włocławek-Toruń, 3-4 czerwca 2009 r.) i wygłoszony podczas obrad referat pt. Niedzielne zgromadzenie centrum i cel życia chrześcijańskiego. Tematykę tę podjął też ks. prof. Konecki na wykładzie monograficznym Świętowanie niedzieli $w$ epoce globalizacji.

- nurt pastoralno-mistagogiczny

Ważne miejsce w zainteresowaniach wynikających zarówno z wyboru, jak i z racji uprawianej dziedziny teologicznej zajmuje w pracy naukowo-dydaktycznej i formacyjno-duszpasterskiej Księdza Profesora nurt pastoralno-mistagogiczny, wyrażający się między innymi w opracowywa- 
niu komentarzy liturgicznych. Przez dziewięć lat ks. K. Konecki zamieszczał w „Ateneum Kapłańskim” [numery: 465-466 (1986) - 515 (1995)] komentarze na niedziele, uroczystości i święta. W sumie opublikował ich aż 533. Zawierają one: wprowadzenie w charakter liturgicznego obchodu, zwięzły wstęp do czytań biblijnych, pełny formularz modlitwy powszechnej, komentarz przed prefacją oraz „słowa na rozesłanie”. Co ważne, teksty te - przy głębi teologicznej i pastoralnej wymowy - charakteryzują się oszczędnością środków wyrazu. Są zwięzłe i mają charakter wybitnie mistagogiczny. Opracowując je, miał Autor na uwadze psychikę współczesnego uczestnika liturgii, jak i podstawowe zasady memoryzacji usłyszanych treści. W tym samym duchu opracował wprowadzenia na dni powszednie całego roku liturgicznego oraz wezwania modlitwy powszechnej (Wprowadzenie do Mszy Świętej i Modlitwa powszechna, Dni powszednie, t. 1, Włocławek 2008, ss. 348).

Sygnalizowany kierunek działalności może wydać się obszarem niezbyt nadającym się do klasyfikacji naukowej. Nie należy jednak zapominać o charakterze dyscypliny uprawianej przez Jubilata, która nie bez powodu będąc teologią systematyczną i metodologicznie uporządkowaną - jest jednocześnie zaliczana do teologii praktycznej. Nie ma wątpliwości, że odpowiednie - zarówno pod względem merytorycznym, jak i formalnym komentarze owocnie wprowadzają w misterium liturgii. Równocześnie tego typu publikacje posiadają duży zasięg odbiorców i kształtują życie liturgiczne. Ponadto, jak uczy doświadczenie, komentarze opracowane przez liturgistów na ogół lepiej spełniają wszelkie kryteria, którym winien podlegać komentarz liturgiczny.

Działania ks. Koneckiego podejmowane w tym zakresie - jak zaznacza sam Jubilat - podyktowane są również troską św. Jana Pawła II, wyrażoną w słowach mających już charakter testamentu, że „najpilniejszym zadaniem jest formacja biblijna i liturgiczna ludu Bożego, pasterzy i wiernych" (Liturgia $w$ dokumentach Jana Pawła II, w: Fides quaerens intellectum. Wiara poszukujaca zrozumienia, red. J. Bagrowicz, M. Mróz, Toruń 2004, s. 245-257; Liturgia w życiu i posłannictwie Kościoła, w: Ocalić dziedzictwo: świętemu Janowi Pawłowi II w X rocznicę nadania doktoratu honoris causa Uniwersytetu Mikołaja Kopernika w Toruniu, red. J. Bagrowicz, W. Karaszewski, Toruń 2015, s. 219-235). Wynikają one także z osobistego doświadczenia, że „liturgia w duszpasterstwie jest 
ciągle niespełnionym postulatem” (Liturgia $w$ duszpasterstwie jest ciagle niespetnionym postulatem, „Ateneum Kapłańskie” 121 (1993) z. 507-508, s. 215-224).

W nurt pastoralno-mistagogiczny wpisują się też publikacje, których celem było przełożenie treści naukowych, niekiedy spekulatywnych, na język i mentalność „zwykłego odbiory”. Taką pozycją jest książka zatytułowana Nasze sprawowanie Eucharystii, Włocławek 2007, ss. 127, którą Jubilat przygotował z myślą, aby dopomóc wiernym w świadomym, pobożnym i owocnym uczestnictwie we Mszy świętej; podobnie artykuł pt. Treści teologiczno-celebracyjne obrzędów Komunii, „Studia Włocławskie” 9 (2006) s. 159-165. Z takim samym zamiarem duszpastersko-formacyjnym zostały również opracowane artykuły na temat sakramentu chorych: Mistagogiczny wymiar sakramentu chorych, „Studia Włocławskie” 8 (2005) s. 216-223; Mistagogiczny wymiar Liturgii godzin, „Studia Włocławskie” 19 (2017) s. 93-104; oraz książka Czas z Chrystusem. Rok liturgiczny, Włocławek 2014, ss. 159.

- nurt józefologiczny

Kierunkiem badań, który w hierarchii naukowych zainteresowań Jubilata odgrywa bardzo istotną rolę jest józefologia. Dyscyplina ta zajmuje się teologiczną refleksją nad osobą, miejscem i rolą świętego Józefa w życiu Jezusa, Maryi i Kościoła. Badania Księdza Profesora idą nie tyle w kierunku promocji samego kultu św. Józefa, ile zmierzają raczej ku poszukiwaniu i uzasadnianiu jego teologicznych podstaw. Skupiają się one na ukazywaniu miejsca św. Józefa w Bożym planie zbawienia. Udział Opiekuna Świętej Rodziny i Patrona Kościoła Świętego w owym planie jest szczególny i niepowtarzalny, i po Maryi pierwszy i najważniejszy. Ks. prof. Krzysztof Konecki w swoich publikacjach wykazuje, że wielkość św. Józefa i jego niezwykłość polega na tym, że Bóg Ojciec okazał mu zaraz po Matce Najświętszej największe zaufanie, składając w jego dłonie ziemskie losy Zbawiciela świata. Poprzez bliskość z Jezusem św. Józef był obecny niemal we wszystkich tajemnicach życia Pana, poprzez które dokonało się dzieło zbawienia. Jest on pierwszym po Maryi uczestnikiem Chrystusowych misteriów, które dzięki obecności Ducha Świętego w Kościele są nieustannie urzeczywistniane na sposób sakramentalny. Stąd 
wynika tak ważna obecność św. Józefa w liturgii, będącej uobecnieniem zbawczych czynów i słów Jezusa.

Dodajmy, że taki sposób uprawiania józefologii wskazał św. Jan Paweł II w adhortacji apostolskiej Redemptoris custos. To „nowe” teologiczne spojrzenie na osobę św. Józefa i jego rolę w tajemnicy Chrystusa i Kościoła jest od wielu lat obecne w wystąpieniach ks. prof. Koneckiego na międzynarodowych kongresach józefologicznych oraz w jego publikacjach: Święty Józef w posoborowych tekstach Mszału i Liturgii godzin, „Ateneum Kapłańskie” 128 (1997) z. 527, s. 73-80; L'assente presenza di San Giuseppe nella liturgia romana, w: San José Custodio de la vida y del amor. Centro de Estudios Josefinos de México, Iztacalco México 2015, s. 357-368; Jak nie mówić i jak mówić... o świętym Józefie, „Homo Dei” 81 (2012) nr 2, s. 115-118; Józefologiczny wymiar działalności naukowej ks. prof. Wojciecha Hanca, w: Ekumenizm. Teologia. Kultura, red. K. Konecki, Z. Pawlak, K. Rulka, Włocławek 2006, s. 55-63; Św. Józef $w$ reformie liturgicznej Soboru Watykańskiego II w: Święty Józef patron na nasze czasy. Akta X Międzynarodowego Kongresu Józefologicznego. Kalisz, Polska, 27 września - 4 października 2009 r., red. A. Latoń, Kalisz 2010, s. 281-296.

Od roku 1985 Jubilat bierze czynny udział w pracach Polskiego Studium Józefologicznego, wygłaszając wiele referatów i komunikatów. Przez wiele lat był sekretarzem tegoż Studium, a w latach 1991-1996 jego przewodniczącym. W tym okresie organizował, bądź współorganizował doroczne sympozja józefologiczne o zasięgu krajowym. Brał także czynny udział w międzynarodowych kongresach józefologicznych. Pokłosiem wygłaszanych referatów stały się kolejne publikacje naukowe. W 1985 roku Jubilat był współorganizatorem międzynarodowego kongresu w Kaliszu; w 1989 roku w Meksyku (Il culto di San Giuseppe nella Collegiata di Kalisz nel 1800, "Estudios Josefinos" 45 (1991) s. 559-564); w 1993 roku w Rzymie (Il culto di San Giuseppe nella diocesi di Włocławek nel secolo XIX, w: San Jose en el siglo XIX. Actas del Sexto Simposio Internacional, Roma 12-19 septiembre 1993, Centro Espanol de investigaciones Josefinas, Vallodolid 1995, s. 433-438); w 1997 roku na Malcie (San Giuseppe nel nuovo Messale di Paolo VI e nella liturgia delle ore), gdzie przewodniczył polskiej delegacji; w 2009 roku ponownie w Kaliszu (San Giuseppe nella riforma liturgica del Vaticano II); w 2013 roku w Ciudad 
Guzman w Meksyku (L'assente presenza di San Giuseppe nella liturgia romana).

- reforma roku liturgicznego i kalendarza

Najnowszym nurtem pracy naukowej ks. prof. Krzysztofa Koneckiego są zagadnienia związane $\mathrm{z}$ soborową reformą roku liturgicznego i kalendarza. Rok liturgiczny zwykle kojarzy się z kalendarzem, czyli z zestawem ruchomych i stałych obchodów liturgicznych: uroczystości, świąt i wspomnień dotyczących życia zarówno Pana Jezusa, Matki Najświętszej, jak i świętych męczenników i wyznawców. Tymczasem istota roku liturgicznego nie polega na rytmicznym następstwie uroczystości, świąt i wspomnień, lecz na wspominaniu i jednoczesnym uobecnianiu in sacramento, w ciągu jednego roku kalendarzowego, całego zbawczego Misterium Paschalnego Chrystusa, całej tajemnicy Jego życia, śmierci i zmartwychwstania, od wcielenia aż do dnia zesłania Ducha Świętego i oczekiwania na powtórne przyjście Chrystusa w dniu Paruzji. Rok kościelny jest obecnością samego Chrystusa (Obecność Chrystusa w liturgii $w$ świetle II Soboru Watykańskiego i dokumentów posoborowych, „Ateneum Kapłańskie” 106 (1986) z. 470, s. 109-116).

Rok kościelny w swej genezie postrzegany jest jako jeden z najpiękniejszych tworów geniuszu katolickiego. Soborowa odnowa liturgii wniosła wiele istotnych zmian, zarówno w strukturę roku liturgicznego, jak i w zawartość kalendarza. W polskiej literaturze liturgicznej ten obszar reformy nie doczekał się jeszcze zbyt wielu kompleksowych opracowań, stąd niektóre artykuły oraz monografia Jubilata traktują o reformie roku liturgicznego i kalendarza: Rok liturgiczny i Kalendarz w reformie Soboru Watykańskiego II, Torun 2010, ss. 302; Posoborowa reforma Kalendarza rzymskiego. Wybrane kwestie redakcyjne, „Roczniki Liturgiczne” 1 (2009) s. 193-205; Święta dewocyjne w Kalendarzu rzymskim z 1969 r. Kwestie redakcyjne, w: In persona Christi, t. 1, red. K. Góźdź, Lublin 2009, s. 1023-1032; Prace redakcyjne nad reforma okresu Wielkiego Postu, „Teologiczne Studia Siedleckie” 12 (2015) s. 241-251; Natura roku kościelnego w Konstytucji o świętej liturgii „Studia Włocławskie” 16 (2014) s. 157-169.

Problematykę roku liturgicznego podjął również Ksiądz Profesor w swoim wykładzie monograficznym na Wydziale Teologicznym UMK 
zatytułowanym Celebracja Misterium Chrystusa w roku liturgicznym. Pedagogiczny wymiar roku liturgicznego.

Dorobek naukowy ks. prof. dr. hab. Krzysztofa Koneckiego jest nie tylko bogaty i różnorodny, lecz także bardzo wartościowy merytorycznie. Odznacza się rzetelnością naukową, dojrzałością w formie i treści, a także przystępnością języka, mimo bardzo specjalistycznej często problematyki. $\mathrm{Na}$ uwagę zasługuje aktualność podejmowanych przez Jubilata kwestii liturgicznych oraz umiejętne włączanie się w aktualny dyskurs naukowy i w bieżące potrzeby pastoralne w zakresie soborowej reformy liturgii i jej percepcji i recepcji w Kościele w Polsce.

Jako bene meritus Jubilat może poszczycić się wieloma odznaczeniami, wyróżnieniami i nagrodami, zarówno uniwersyteckimi, jak i kościelnymi. Za osiągnięcia uzyskane w działalności naukowej ks. prof. dr hab. Krzysztof Konecki w ciągu minionych lat kilkakrotnie otrzymywał wyróżnienia i nagrody Rektora Uniwersytetu Mikołaja Kopernika w Toruniu. Również kolejni Biskupi Włocławscy dostrzegali jego pracę duszpasterską, kapłańską postawę oraz długoletnią pracę naukowo-dydaktyczną, zwłaszcza w Wyższym Seminarium Duchownym we Włocławku. W roku 1993 Ksiądz Profesor został odznaczony godnością kapelana Ojca Świętego, w roku 2003 - kanonika gremialnego Kapituły Bazyliki Katedralnej we Włocławku, a w roku 2008 - prałata honorowego Jego Świątobliwości. W 2012 roku Jubilat został prepozytem Prześwietnej Kapituły Katedralnej we Włocławku, a w roku 2014 otrzymał tytuł infułata, który Biskup Włocławski związał z godnością prepozyta.

Ad multos annos. 